\title{
Regulation, Non-Market Values, and the Administrative State: A Comment on Professor Stewart
}

\author{
Peter H. Schuck†
}

We had every reason to anticipate that Professor Stewart would provide an incisive, provocative; and encompassing analysis. He has not disappointed us. His subject-the problem of legitimating contemporary regulation in terms of what he calls a "liberal political theory"-is profoundly important. The relationship between that theory and regulatory practice, Professor Stewart argues, is deeply problematic. While not altogether clear about whether these pervasive conflicts inhere in the regulatory enterprise or simply reflect the particular, contingent forms that our regulatory programs have taken, he leaves no doubt that these conflicts are deeply rooted in our regulatory purposes, techniques, and institutional structures.

Professor Stewart enumerates three "bases" of regulation, by which I take him to mean justifications for administrative intervention into markets and other domains of once-private decisionmaking. Regulation, in his view, seeks to secure rights, to promote efficiency, and to protect "noncommodity values." In attempting to do so, however, regulation inevitably violates one or both of what Stewart regards as the fundamental liberal values-the "public interest" and "neutrality" principles. ${ }^{2}$ Since these same three "bases" of regulation also comprise the essential purposes of liberal government, Stewart's conclusion would undermine not merely the moral foundations of regulation but also those of the liberal state itself.

In this comment, I want to argue that the problem of legitimating regulation is both easier and more difficult than Professor Stewart's ominous logic suggests. It is easier in the sense that the old terms of debate with liberalism no longer reflect (if they ever did) our dominant public values and conceptions. The old principles are thus no longer the most relevant normative criteria by which to evaluate contemporary (or more precisely, pre-1981) regulation. Legitimation is more difficult, however, in the sense

$\dagger$ Professor of Law, Yale University.

1. Stewart has explored this trinity of purposes in a related context. See Stewart \& Sunstein, Public Programs and Private Rights, 95 HARv. L. Rev. 1193 (1982).

2. Stewart, Regulation in a Liberal State: The Role of Non-Commodity Values, 92 YALE L.J. 1357,1358 (1983). 
that the new norms that have supplemented them probably cannot be vindicated by regulation under existing or foreseeable political and social conditions.

In sketching out this argument, I wish to make three points. First, the evolution of the administrative state has transformed, and been transformed by, both the content of liberalism and the shifting nature of regulation. Professor Stewart surely appreciates these changes, but he does not adequately explore their implications for his analysis. Second, the most important aspect of those transformations, at least for purposes of the present discussion, is the emergence of wealth redistribution through regulation. Such redistribution has become an essential feature of the administrative state, and one legitimated by the values of post-New Deal liberalism. Professor Stewart of course recognizes that regulatory redistribution occurs, ${ }^{3}$ but his discussion has curiously little to say about it, considering that wealth redistribution is probably the preeminent non-commodity value guiding regulation. Finally, he leaves the large institutional and intellectual obstacles to efficient and equitable wealth redistribution through regulation substantially unexplored, suggesting a worthy agenda for students of the administrative state; one that Professor Stewart's own work has helped to advance and shape.

In order to understand the problem that regulation poses for liberalism, we must first attempt to define liberalism in a world in which relentless economic, social, and political pressures have profoundly altered both the character and consequences of regulation." Equally important, if perhaps less obvious, these changes have altered the nature of post-New Deal liberalism as well. Indeed, the question of whether contemporary public ideology even deserves to retain the title of "liberalism" or has instead evolved into something quite different is problematic. It is, however, a question I shall not address.

No society that truly adhered to the public interest and neutrality tenets-especially as Professor Stewart defines them-could possibly have created agencies like the Consumer Product Safety Commission, the EEOG, the Department of Energy, and OSHA, each designed to mobilize public authority and marshal private resources on behalf of particular interest groups. Such a society would not devote fully $47.9 \%$ of its federal budget to direct income transfers, ${ }^{\mathrm{b}}$ nor countenance an unelected judiciary

3. Posner, Taxation by Regulation, 2 BELL J. ECON. 22 (1971).

4. Stewart, supra note 2 , at $1545-46$.

5. U.S. DEP'T OF COMMERCE, STATISTICAL ABSTRAGT OF THE UNITED STATES 319 (4th ed. 1984). 
that reallocates scarce public funds on behalf of vulnerable minorities. ${ }^{b}$ That we have celebrated these redistributive measures as expressions of the highest aspirations of a liberal society suggests that, for better or worse, we have left Professor Stewart's fundamental principles far behind. Today, regulation implies not a minor adjustment in liberal theory but a paradigm shift. Evaluating contemporary regulation in light of the preNew Deal understanding of liberalism is like planning a sea voyage on the premise that the earth is flat.

This is not the occasion to develop a normative theory of the administrative state adequate to the realities that the vast majority of Americans now take for granted. Several ambitious efforts to construct such a theory have been made in recent years, ${ }^{7}$ and others will surely follow. My very modest purpose here is simply to call attention to some new social facts and values that must shape any broad theory because they affect not only the relationship of regulation to liberalism but the content of liberal values themselves. I shall mention only three. The first is the emerging conception of the individual-in-society. The second is the erosion of the distinction between private and public life that supported the traditional view of law in a liberal society. The third is society's loss of confidence in both the market and governmental regulation. Taken together, these changes have spawned a new conception of the relationship between government and liberal values.

\section{A. The Individual in Society}

The administrative state, as Professor Stewart indicates, is in part a mechanism for domesticating the centralizing markets and technologies and pervasive spillover effects that characterize modern life. ${ }^{8}$ But it bespeaks and responds to an even more fundamental change in social consciousness. Gilder-speak aside, ${ }^{9}$ the dominant vocabulary of social discourse and even of political rhetoric no longer depicts the individual as a self-reliant, self-defining member of the community. Nor does that vocabulary view the individual as someone whose calculated choices register a unique set of preferences that a good society should ratify and implement in the marketplace. Today, such an individual seems a throwback, an artifact of pre-modern consciousness bearing as much relationship to contem-

6. See Plyler v. Doe, 457 U.S. 202 (1982) (holding unconstitutional Texas' denial of state funds to local school districts for education of children of illegal aliens).

7. See, e.g., B. ACKERMAN, SOcIal JUsTICE IN THE LIBERAL STATE (1980) (explaining inner coherence of modern liberalism); J. RAWLS, A THEORY OF JUSTICE (1971) (generalizing theory of social contract).

8. See Stewart, supra note 2, at 1546.

9. See G. GILDER, WEALTH AND POVERTY (1981). 
porary men and women as a medieval hamlet bears to downtown Manhattan. In modern parlance, the individual is little more than a mirror of social reality. Society, in this view, is pathological and the individual its victim. His desires, capacities, self-understandings, and behavior reflect the play of large social forces beyond his control. Because these forces determine his fate far more than individual "merit," he cannot be held unambiguously responsible for the good and ill fortune that they mete out. His preferences as a consumer are poorly informed and socially conditioned, imposed from without as much as animated from within. As employee, he is at the mercy of impersonal market conditions, technological patterns, and workplace hierarchies. As citizen, he is a prisoner of history, his impotence rooted in long-standing social patterns of discrimination, ignorance, and manipulation.

This emergent conception of the individual as social construct inevitably undermines both the plausibility and the moral appeal of the liberal tenets that Professor Stewart invokes. If an individual's preferences are socially shaped, there is no reason in principle why they cannot be socially overridden. If opportunities are socially created or constrained, they can be reconstituted in the name of social equity. If social forces leave citizens vulnerable to the depredations of those whom society favors, society can intervene to repair its earlier mischief. Given these assumptions about social responsibility for existing power differences and injustices, we could hardly subscribe to an ideology that compelled the state to be indifferent to which private interests were served and to be neutral as to which conceptions of the good were embodied in public policies and practices. Only in a world that spoke the vocabulary of atomized individualism and the grammar of the minimal state might the social indifference to ultimate ends implicit in Professor Stewart's neutrality and public interest principles begin to make sense. In such a world, government regulation would indeed raise the kind of profound questions of legitimacy and political theory that Professor Stewart pursues. By and large, however, that was the world that the New Deal set about to displace.

\section{B. The Erosion of Private Law}

In the pre-New Deal world, law had a decidedly limited function, its dimensions defined and secured by certain conventional boundaries. One of the most important boundaries was that between the public domain, in which regulatory intervention was regarded as legitimate, and the private domain, in which such intervention was presumptively illegitimate. Over time, of course, that boundary shifted, but no one doubted that the line separated morally and constitutionally distinct spheres of activity.

Today, that line has not merely shifted but has largely disappeared. 
The administrative state has thrust national public law into many enclaves previously considered to be matters of private, consensual determination-employment relationships, individual consumption patterns, university curricula, professional practices, and religious observances, to name just a few. The socialization of moral responsibility and individual choice, discussed earlier, has converged with an increasingly public administration of traditionally private concerns. When wealth is considered to be socially created, the malleable product of socially conditioned opportunities and incentives, the logical premise and moral sanction exist for abolishing the distinction between public and private. The failure to tax wealth comes to be viewed as a "tax expenditure," tantamount to a public subsidy of untaxed activities. ${ }^{10}$ All activity that affects opportunities and incentives-which is to say, virtually everything-becomes by definition "affected with the public interest."

When the public-private distinction disintegrates, so too does the strong mooring that liberalism provides for the distinction between taxation and regulation. Taxation-and-transfer is perfectly consistent with liberal principles, maintains Stewart, but he believes regulatory redistribution to be decidedly antagonistic to those principles. ${ }^{11}$ But if wealth and other life opportunities are viewed as socially determined and subject to social reallocation in the service of publicly defined ends, no liberal tenet prevents accomplishing that reallocation through regulation of privately held resources rather than (or in addition to) taxation of those same resources. There may well be weighty reasons, of course, for the state to proceed through one form rather than another-to spend public funds on health care for the poor rather than to compel employers or hospitals to provide that care, for example. ${ }^{12}$ But those reasons certainly do not go to the integrity of liberal principles or to the social legitimacy of the technique that is employed. ${ }^{13}$ Both taxation and regulation are intended to effect a forced wealth transfer; both are but one redistributional string in the bow of the administrative state.

In such a world, it is not at all clear what is meant by notions of "purely private ends" and governmental "neutrality" with respect to various conceptions of the public good. Nor is it clear how these ideas can

10. See generally Surrey, Tax Incentives as a Device for Implementing Government Policy: A Comparison with Direct Government Expenditures, 83 HARV. L. REV. 705 (1970)(arguing inferiority of tax incentive to direct subsidy as means of achieving social goals).

11. Stewart, supra note 2, at 1572-73.

12. But see 42 G.F.R. $\S \S 124.501-.512$ (1983) (Hill-Burton Act regulations requiring certain hospitals to provide "reasonable volume of services to persons unable to pay").

13. E.g., efficiency and budget accountability. See P. Schuck, Designing Hospital Care Subsidies for the Poor (unpublished paper delivered at symposium on uncompensated care, Vanderbilt University, April 5, 1984). 
operate as the kind of constraint upon government that Professor Stewart's version of liberal theory envisions. In the world of the administrative state, the "private ends" of pre-New Deal liberalism are viewed not as ultimate moral categories but as historically contingent ones to be routinely subordinated or harnessed to public purposes. Private factions drive the pluralist engine that animates and defines those public purposes; the administrative state can no more maintain a neutral detachment from those factions than an organism can be indifferent to the food it ingests. Having rejected liberalism's belief that private vice is public virtue when it operates in the economic marketplace, the administrative state must embrace that same credo in the political marketplace, where its goals and priorities are defined. ${ }^{14}$

\section{The Efficacy of Public Law}

The liberal theory that antedated the administrative state was grounded in profound skepticism about the efficacy of government. Government seldom ventured beyond certain limited though important realms-war (where fear of a common enemy could concert disparate wills), taxation (which took place largely through the collection of tariffs, a relatively straightforward matter), certain public goods (which would be provided only if government supplied them), the resolution of individual disputes (which required only umpireal detachment and a process for enforcement), and an occasional, small-scale regulatory program. To believe that government could discharge these functions required no heroic assumptions about the capacity of law and bureaucracy to reshape and energize the fundamental institutions and practices of society. It required only the belief that government could do what governments everywhere had always done. For those functions, even a state structure as constitutionally fragmented as ours could be expected to perform with tolerable effectiveness. Liberal theory was not much troubled over the legitimacy of governmental power-federalism aside, the crucial questions had been definitively resolved in 1787. Moreover, in view of the relatively limited and familiar tasks, the problem of competence did not seem particularly acute. ${ }^{15}$

The emergence of the administrative state has completely altered the nature of the problem that regulation poses for liberal theory. Today, the challenge is no longer to legitimate public assertions of regulatory power, as Professor Stewart suggests. ${ }^{16}$ The decisive stage of that battle was reached fifty years ago, and the outcome, secured through the transforma-

14. See B. MANDEVILle, The Fable OF THE BEES 371 (P. Harth ed. 1970).

15. See Wilson, The Rise of the Bureaucratic State, 41 PUB. INTEREST 77, 77-78 (1975).

16. Stewart, supra note 2 , at $1537-38$. 
tion of public values, has long been clear. The challenge is rather to demonstrate how that conceded moral authority can be implemented efficiently, equitably, and democratically under the conditions that prevail in contemporary American society. The crude tools of governance of the administrative state, and its dismal record to date, hardly inspire confidence that the challenge of implementation can be fully met, ${ }^{17}$ especially given the ambitious regulatory agenda of the administrative state. It is difficult enough for a computer-age society to govern itself through an eighteenthcentury apparatus, especially one that in its essential respects-a radical decentralization of both geographical and institutional power-remains remarkably unchanged. When society undertakes to use the apparatus to achieve equality, protect the biosphere, perfect markets, control risk, and guide a staggeringly complex economy through unexplored terrain, a liberal theory devised not to energize the state but to incapacitate it cannot be expected to supply the normative principles necessary to chart the government's ambitious course.

The rise of the administrative state, then, has both reflected and caused certain pervasive social changes-in our conception of individual competence and responsibility, in the domains in which public power is exercised, and in the demands of governmental competence posed by new regulatory and redistributive visions. Taken together, these changes have so fundamentally transformed the nature, scale, and conception of government that the liberal norms against which Professor Stewart would measure regulation have become largely irrelevant to that essential evaluative task. It is as if we sought to understand the problem of a nuclear exchange by appraising it according to von Clausewitz's strictures on the conduct for traditional wars. ${ }^{18}$ We would find answers, to be sure, but for the most part they would be answers to the wrong questions.

II.

Professor Stewart acknowledges that "a purely private conception of liberty" may be impoverished. He therefore seeks a more adequate conception of liberalism, one that takes a more sympathetic view of regulation. ${ }^{19}$ He seeks to find it in the notion of non-commodity values, and I believe that he is searching in the right place: The notion of noncommodity values illuminates many regulatory phenomena that simply cannot otherwise be adequately explained. Until recently, society's de-

17. See generally Schuck, Book Review, 90 YALE L.J. 702 (1981) (reviewing THE POLITICS of REGULATION (J. Wilson ed. 1981)).

18. See generally C. vON ClaUSEWITZ, ON WAR (M. Howard \& P. Paret trans. 1976).

19. Stewart, supra note 2 , at 1567. 
mand for non-commodity values appeared no less insatiable than its desire for commodity goods. Even during the current period of economic stringency, public support for environmental and consumer protection remains widely shared and intense. It is difficult to believe that this commitment to environmental and consumer regulation reflects nothing more in the public mind than a desire for market efficiency.

Nevertheless, Professor Stewart's attempt to use non-commodity values to explain or justify (one cannot always be sure which) regulation creates a number of difficulties. First, and perhaps most striking, his account of non-commodity values omits precisely that purpose-redistribution of private wealth through forced transfers from one social group to another-that is essential to understanding both liberalism and regulation in their post-New Deal incarnations. Sometimes this redistributive objective is explicit, as in long-distance telephone rates designed to subsidize local service $^{\mathbf{2 0}}$ or regulated interest rate ceilings intended to reduce mortgage rates to homeowners. ${ }^{21}$ In other cases, that purpose may be inferred with the aid of certain plausible assumptions about regulatory behavior. ${ }^{22}$ In still others, redistribution is best understood as an unanticipated effect of regulation rather than a self-conscious regulatory purpose. ${ }^{23}$

Professor Stewart's omission is evidently intentional. His trinity of regulatory purposes seems designed to be exhaustive; at least I can find no intimation that there might be others. Moreover, his enumeration and elaboration of non-commodity values strongly imply that he does not intend to include wealth redistribution among them. ${ }^{24} \mathrm{I}$ do not mean to suggest that he neglects redistribution altogether. Indeed, his discussion of the three bases of regulation implies that governmental attempts to secure rights, enhance economic efficiency, and vindicate non-commodity values may entail, either explicitly or implicitly, the forced transfer of wealth. And many of the specific regulatory policies with which he embellishes his analysis amply illustrate that proposition. ${ }^{25} \mathrm{My}$ point is that rather than treating wealth distribution through regulation as a primary non-market value, Stewart treats it either as a contradiction of liberal principles, as

20. See American Tel. \& Tel. Co., 9 F.C.C. 2d 30, 110-11 (1967) (subsidization of intrastate telephone rates by interstate rates); see generally MacAvoy \& Robinson, Winning by Losing: The AT\&T Settlement and Its Impact on Telecommunications, 1 YALE J. ON REG. 1, 2-3 (1983).

21. See Federal Reserve Board, Regulation Q, 12 C.F.R. $\$ \S 217.0-.160$ (1984).

22. See generally Stigler, The Theory of Economic Regulation, 2 BELL J. ECON. \& MGMT. SCI. 3 (1971).

23. Perhaps the classic example is the statutorily regulated minimum wage, which appears to redistribute income away from precisely those workers it is designed to help. See J. PETERSON, MINIMUM WAGES: MEASURES AND INDUSTRY EFFECTS 1-5 (1981).

24. Stewart, supra note 2, at 1567-69. Professor Klevorick has made a similar observation in commenting upon an earlier paper of Professor Stewart's. Klevorick, Comments, in CoLLECTIVE DECISION MAKING: APPLICATIONS fROM PUBLIC ChOICE TheORY 233, 236 (C. Russell ed. 1979).

25. Stewart, supra note 2 , at 1570-71, 1576-77. 
when he contrasts taxation and "taxation by regulation," by-product of liberalism's pursuit of other ends.

In truth, wealth redistribution is often not simply an ancillary consequence of regulation but also its animating purpose. ${ }^{27}$ If wealth redistribution cannot be reconciled with the tenets of liberal theory, then either we are no longer a liberal polity, in which case an incompatibility between regulation and liberalism is predictable, or liberal theory must be reformulated in light of the new social norms and facts. I am not suggesting, of course, that a good normative theory must yield to discordant facts; even the administrative state cannot extract "ought" from "is." But when "liberal" principles deny the non-commodity aspirations of a society that conceives of itself as liberal-aspirations deeply embedded in that society's experience, law, and institutions-one may well conclude that it is the theory, not the practice, that is wanting.

A second difficulty with non-commodity values as an explanation for (or justification of) regulation is that it is a residual category, a catch-all for any regulatory intervention that neither creates entitlements nor seeks to maximize wealth. As such, this explanation is delightfully openended-an analyst's deus ex machina. Almost any purpose can qualify as a "non-commodity" value. (Indeed, some regulatory policies can plausibly be justified on all three grounds - the maximization of wealth, the advancement of non-commodity values, and the creation of rights.) Since characterizing an intervention as advancing "non-commodity" values can "explain" or "justify" virtually anything, the category lacks resolving power.

A third and related problem with non-commodity values, especially in comparison with Professor Stewart's other two bases of regulation, is its irreducible ambiguity. One may laud the non-commodity values of aspiration, mutuality, civic virtue, and diversity but still worry about their radical subjectivity. Little about them is certain except that a multitude of regulatory sins will be committed in their name. What does it mean to regulate civic virtue? (Perhaps the Federal Election Commission can tell us.) Can such regulation be confined to the kind of non-controversial procedural, diversity-enhancing interventions that Professor Stewart apparently has in mind? Would this notion of regulating civic virtue preclude adopting the substantive regulatory agenda of the Moral Majority? How are non-market values to be traded off against one another and against market values and legal entitlements?

It is no criticism of Professor Stewart's analysis that he does not answer

26. Id. at 1541 .

27. See supra p. 1609. 
such questions. Instead, the questions simply suggest the need to clarify the content of non-market values at this particular historical moment and to explore their implications for both a new understanding of liberal principles and a critique and reform of regulation.

\section{III.}

Although wealth redistribution has become and continues to be an increasingly important goal of regulation, it by no means follows that regulation is an especially effective technique for accomplishing that end. In principle, of course, any given redistribution could be achieved more efficiently and fairly through taxation-and-transfer. ${ }^{28}$ But that mode of redistribution looks very different-and far less attractive-from the point of view of the politicians who would have to vote to raise taxes, appropriate funds, and identify intended losers and gainers with particularity. Regulation allows these politicians to accomplish redistribution surreptitiously, and also to create an agency that can both serve as a continuing symbol of their commitment to the favored constituency and offer numerous opportunities for the exercise of political influence. Even assuming significant losses in target efficiency, horizontal equity, and administrative cost, then, redistribution-minded politicians may prefer to require utilities to sell electricity to the poor and elderly at low "lifeline" rates, force landlords to upgrade the quality of housing, and order railroads to serve distressed and unprofitable communities. Such politicians know that a more direct assault on the public fisc on behalf of such groups will surely fail. Thus, compared to the likely alternative of the status quo, redistribution through regulation may serve the interests not only of politicians but of the favored constituency as well. And when one adds interest groups that supply advocacy services, bureaucrats that specialize in regulatory management, and a general public that takes comfort in political symbols and the promise of programmatic substance, redistribution through regulation becomes almost irresistable. ${ }^{2 \theta}$ This is efficiency but of a distinctive kind, with due apologies to the economists.

When the current anti-regulatory wave has spent itself, as it almost certainly will, and the non-commodity value of wealth redistribution again finds political expression, two important questions not directly addressed by Professor Stewart but illuminated by his analysis will remain. First, can regulation actually redistribute wealth in the desired way? And second, can regulation-redistributive or otherwise-be rendered accountable

28. See R. ZEckhauser, USING THE Wrong TOOL: THE PURSUIT OF REDISTRIBUTION THROUGH REGULATION 11-14 (Chamber of Commerce 1979).

29. See Schuck, supra note 17, at 714-16. 
to the rule of law? There are reasons to be skeptical on both counts, and thus to question the legitimacy of regulation even under post-New Deal liberalism. The existing distribution of wealth severely hampers efforts to use regulation to alter that distribution. To do business with the administrative state often requires access to professional advocates and other "weapons of middle class warfare" least available to precisely those who need them most. ${ }^{30}$ To the poor and unsophisticated, the politicalbureaucratic process that ultimately allocates the regulatory dispensations seems opaque and forbidding. ${ }^{31}$ The disadvantaged seem especially confined by the harsh logic of Mancur Olson's organizational paradox. ${ }^{32}$

Effective regulatory redistribution faces non-political obstacles as well. General rules, for example, cannot make the kinds of need-based discriminations that equitable and efficient redistribution requires, yet we are unlikely to countenance broad grants of bureaucratic discretion when such important interests are at stake. ${ }^{33}$ The institutional and intellectual barriers to effective regulatory redistribution are also considerable. As my colleague Michael Graetz has demonstrated, and as the current controversy over the effect of the corporate income tax confirms, the ultimate incidence of even a straightforward tax is elusive. ${ }^{34}$ The distributional effects of most regulatory programs are likely to be even more difficult to predict. ${ }^{35}$

The role of courts in subjecting regulation to the rule of law is also problematic, as Stewart's earlier work has emphasized.$^{36}$ While discussing non-commodity values generally, Stewart's current piece reminds us that reviewing courts are even less able to mobilize the organizational intelligence and institutional power necessary to implement and enforce such values than they are with respect to commodity values. ${ }^{37}$ This is so even if we assume that agencies can distill non-commodity values from the governing legislation and that judges can independently give them coherent content. Professor Stewart's account of the D.C. Circuit's long twilight struggle with the FCG over program format speaks volumes on this

30. For a development of this point, see Galanter, Why the 'Haves' Come Out Ahead: Speculations on the Limits of Legal Change, 9 LAW \& SOC'Y REV. 95 (1974).

31. Simon, Legality, Bureaucracy and Class in the Welfare System, 92 YALE L.J. 1198, 1221 (1983).

32. M. OLSON, THE LOGIC OF COLLECTIVE ACTION 21, 43-45 (rev. ed. 1971) (because of freerider problem, widely diffused interests difficult to organize).

33. Simon, supra note 31 , at 1223-24.

34. Graetz, Assessing the Distributional Effects of Income Tax Revision: Some Lessons From Incidence Analysis, 4 J. LEGAL STUD. 351, 353-55 (1975).

35. See Schuck, supra note 17, at 720 (regulation of complex markets and institutions produces unpredictable consequences).

36. See Stewart, The Reformation of American Administrative Law, 88 HARV. L. REV. 1667, 1781-84 (1975).

37. Stewart, supra note 2 , at 1586-87. 
score. ${ }^{38}$ The same court's interminable arm-wrestle with the Commission over license renewal standards, chronicled in the Breyer-Stewart casebook, demonstrates (if anyone still had any doubts) that the program-format struggle is no isolated example. ${ }^{3 \theta}$

It is not enough, then, for reviewing courts to discern non-commodity values, analyze their regulatory implications in particular markets, and command that they be vindicated, difficult as those tasks (especially the first two) may be. If regulation designed to secure non-commodity values (including redistribution) is to fulfill its promise, courts must be prepared to do a good deal more than simply identify substantive errors or procedural defects and remand for yet another agency decision. For example, continuing the status quo pending a protracted, multiple-remand litigation frustrates the advancement of the relevant non-commodity value. A court's ability to protect that value may therefore depend upon its willingness to adopt unconventional, institutionally demanding, and arguably illegitimate strategies. Courts may have to devise ways to shift the burdens of delay from the intended beneficiaries of the non-commodity value to those whose conduct is preventing its realization. They may be obliged to intrude even further than they already have into the realm of regulatory policymaking and discretionary choice, perhaps by writing far more specific and constraining remand orders. They may even have to write the agency's regulations for it, as the D.G. Circuit essentially did in the Alabama Power case. ${ }^{10}$ They must be willing in such cases not only to "stay the course" with bulldog (or kamikaze) tenacity but to shape that course with the practical wisdom and substantive vision of the programmatic "expert." Whether the public, the legal scholars or the courts themselves would find such an administrative law congenial is, of course, another question. Indeed, it is one best left for another symposium.

38. Stewart, supra note 2 , at 1583-84.

39. S. BREYER \& R. STEWART, ADMINISTRATIVE LAW AND REGULATORY POLICY 377-95 (1979); id. at 53-60 (Supp. 1982).

40. Alabama Power Co. v. Costle, 636 F.2d 323 (D.C. Cir. 1979). 